\title{
PENGARUH LIGHT MASSAGE TERHADAP TEKANAN DARAH PENDERITA HIPERTENSI PRIMER DI KABUPATEN BANYUMAS
}

\author{
Sidik Awaludin, Arif Setyo Upoyo, Iwan Purnawan \\ Jurusan Keperawatan FIKES Unsoed Purwokerto
}

\begin{abstract}
Blood Pressure, Light Massage, Hypertention. The impact of hypertension leads to heart attack, renal failure and stroke if the blood pressure is not controlled. Light massage is a complementary therapy for blood pressure control of patients with primary hypertension. Light massage can cause a relaxation response and reduce stress. The purpose of this study was to identify the effect of light massage on the decrease in blood pressure. Research design is pre experimental. The number of respondents in this study were 16 respondents. Sampling technique used is purposive sampling. The study was conducted by measuring blood pressure before and after light massage therapy. Blood pressure measurement using digital tensimeter. Test the difference in blood pressure before and after intervention using Wilcoxon test. The results showed a significant difference in blood pressure before and after treatment in the group receiving light massage therapy ( $p$ value 0.035). Light massage affects the decrease in blood pressure in patients with primary hypertension.
\end{abstract}

Keywords: Blood Pressure, Light Massage, Hypertention

Abstrak: Tekanan Darah, Light Massage, Hipertensi. Dampak hipertensi menyebabkan seragan jantung, gagal ginjal ginjal dan stroke jika tekanan darah nya tidak terkendalikan. Light massage merupakan terapi komplementer untuk pengendalian tekanan darah penderita Hipertensi primer. Light massage dapat menyebabkan respon relaksasi dan menurunkan stres. Tujuan penelitian ini adalah untuk mengidentifikasi pengaruh light massage terhadap penurunan tekanan darah. Desain penelitian yaitu pra eksperimental. Jumlah responden pada penelitian ini yaitu 16 responden. teknik sampling yang digunakan yaitu purposive sampling. Penelitian dilakukan dengan mengukur tekanan darah sebelum dan setelah dilakukan terapi light massage. Pegukuran tekanan darah menggunakan tensimeter digital. Pengujian perbedaan tekanan darah sebelum dan setelah intervensi menggunakan Wilcoxon test. Hasil menunjukkan ada perbedaan tekanan darah yang bermakna sebelum dan setelah perlakuan pada kelompok yang mendapat terapi light massage (nilai $p$ 0,035). Light massage berpengaruh terhadap penurunan tekanan darah pada penderita hipertensi primer.

Kata Kunci: Tekanan Darah, Light Massage, Hipertensi

\section{PENDAHULUAN}

Hipertensi masih menjadi masalah serius di dunia (Shapo et al, 2003). Kejadian hipertensi atau tekanan darah tinggi di Indonesia masih tinggi. Hasil
Riset Kesehatan Dasar (Riskesdas) 2013 menunjukkan, sebagian besar kasus hipertensi di masyarakat belum terdiagnosis. Hal ini terlihat dari hasil pengukuran tekanan darah pada usia lebih 
dari 18 tahun ditemukan prevalensi hipertensi di Indonesia sebesar 25,8\%, dimana hanya $9,2 \%$ penduduk yang sudah mengetahui memiliki hipertensi dan hanya $0,1 \%$ kasus yang minum obat hipertensi sendiri.Kejadian hipertensi di Jawa Tengah juga cukup tinggi sebesar 26,4\% (Riskesdas, 2013). Hasil survey kejadian hipertensi tahun 2013 di RSUD Banyumas dalam rentang waktu empat bulan tergolong tinggi dengan jumlah kunjungan penderita hipertensi mencapai 2190 kunjungan.

Hipertensi merupakan faktor risiko yang paling berpengaruh terhadap kejadian serangan jantung dan gangguan pembuluh darah. Hipertensi syang dialami seringnya tidak menunjukkan gejala, sehingga akan disadari ketika telah menyebabkan gangguan organ seperti gangguan fungsi jantung atau stroke. Fenomena tersebut diakibatkan oleh tidak terkontrolnya tekanan darah pada penderitanya. Faktor penyebab utama tidak terkontrolnya tekanan darah adalah faktor stress dan ketidakpatuhan pada diet (Upoyo, 2014).

Stress psikologis berpengaruh terhadap timbulnya hipertensi esensial. Stress berpengauh terhadap peningkatan tekanan darah melalui aktivasi saraf simpatis. Peningkatan aktivitas saraf simpatis dapat meningkatkan tekanan darah secara intermitten (tidak menentu). Apabila stress berkepanjangan, dapat mengakibatkan tekanan darah menetap tinggi (Junaidi, 2010; Simone et al, 2005).

Pijat merupakan sentuhan pada jaringan lunak tubuh dengan menggunakan tangan sebagai alat untuk menimbulkan efek positif dari pembuluh darah, otot, dan sistem syaraf tubuh (Clay \& Pounds, 2008). Terapi keperawatan seperti pijat dapat memicu pelepasan endorfin sehingga menghasilkan perasaan nyaman pada pasien, selain itu dapat terjadi reduksi hormon stres seperti adrenalin, kortisol, dan norephinefrin. Efek lain dari terapi pijat adalah mengurangi tekanan pada ototsehingga meningkatkan relaksasi, memperbaiki sirkulasi darah, dan menurunkan tekanan darah sistolik dan diastolik (Aorella, 2005; Hernandez et al, 2000; Morales,2008; Wiyoto, 2011).

\section{METODE PENELITIAN}

Desain penelitian ini yaitu pra eksperimen. Subyek penelitian adalah penderita hipertensi primer. Jumlah responden dalam penelitia ini 16 responden. Tekanik sampling yang digunakan yaitu purposive sampling. Responden diberikan terapi light massage. Tekanan darah diukur menggunakan tensimeter digital sebelum dan setelah intervensi. Analisis data menggunakan Wilxocon test.

\section{HASIL PENELITIAN}

A. Karakteristik responden Karakteristik responden penelitian ditampilkan pada tabel 1 .

\section{Tabel 1}

Karakteristik Responden

\begin{tabular}{lcc}
\hline \multirow{2}{*}{ Karakteristik } & \multicolumn{2}{c}{$\begin{array}{c}\text { Kelompok Light } \\
\text { massage }(\mathrm{n}=16)\end{array}$} \\
\cline { 2 - 3 } & $\mathrm{f}$ & $\%$ \\
\hline Umur (Tahun) & 10 & 62,50 \\
$50-60$ & 3 & 18,75 \\
$61-70$ & 3 & 18,75 \\
$>70$ & & \\
Jenis kelamin & 3 & 18,75 \\
Laki - laki & 13 & 81,25 \\
Perempuan & & \\
Tingkat Pendidikan & 15 & 93,75 \\
SD & 0 & 0,00 \\
SMP & 1 & 6,25 \\
SMA & & \\
\hline
\end{tabular}


Berdasarkan tabel 1 diketahui bahwa semua penderita hipertensi berusia $>50$ tahun, yang didominasi oleh perempuan $(81,25 \%)$. Pada tabel tersebut diketahui pula bahwa sebagian besar penderita hipertensi primer berpendidikan SD $(93,75 \%)$.

B. Tekanan darah sebelum dan setelah perlakuan

Tekanan darah sebelum dan setelah perlakuan disajiakan pada tabel 2 .

Tabel 2.

Tekanan Darah Sebelum Dan Setelah Perlakuan

\begin{tabular}{|c|c|c|c|c|c|}
\hline \multirow[t]{2}{*}{ Kelompok } & \multicolumn{2}{|c|}{ Sebelum } & \multicolumn{2}{|c|}{ Setelah } & \multirow{2}{*}{$p$} \\
\hline & $\bar{x}$ & SD & $\bar{x}$ & SD & \\
\hline $\begin{array}{l}\text { Light } \\
\text { Massage }\end{array}$ & 159,06 & 11,45 & $\begin{array}{c}154, \\
00\end{array}$ & $\begin{array}{c}17,5 \\
3\end{array}$ & $\begin{array}{l}0,03 \\
5\end{array}$ \\
\hline
\end{tabular}

Berdasarkan tabel 2 dapat diketahui bahwa tekanan darah sistolik sebelum dan setelah dilakukan tindakan light massage mempunyai perbedaan yang signifikan ( $\mathrm{p}$ value $<0,035)$.

\section{PEMBAHASAN}

Laki- laki dan perempuan setelah memasuki usia 50 - 60 tahun mempunyai risiko peningkatan tekanan darah meningkat. Pada wanita peningkatan terjadi setelah menapouse. Peningkatan tekanan darah sistolik sampai usia 70 tahun disebabkan oleh penurunan elatisitas filamen pada aorta dan arteri besar. Selain hal tersebut pada usia lanjut tekanan darah dipengaruhi oleh intake natrium, volume cairan ekstra seluler dan serum protein. Umur juga berhubungan dengan produksi katekolamin. Pada usia lanjut produksi noreprineprin meningkat, konsentrasi renin menurun, konsentrasi aldosteron plasma dan urin menurun. (Gray, 2009; Sigarlaki \& Herleke, 2006)
Lansia terjadi perubahan struktur pembuluh darah yaitu penurunan elatisitas otot polos pembuluh darah yang dapat meningkatkan resistansi perifer meningkat. Selain hal tersebut, semakin lanjut usia semakin tebal timbunan lemak atau plak pada dinding mukosa pembuluh darah yang mengakibatkan kekakuan pembuluh darah. Ketika memasuki lansia banyak timbul faktor risiko lain dari hipertensi yang merupakan konsekuensi proses penuaan alamiah, dan karenanya akan meningkatkan kemungkinan hipertensi (Smeltzer, 2008) . Faktor risiko tersebut yaitu :1) Perubahan struktur pembuluh darah; 2) Kekakuan pembuluh darah dan menurunnya daya lentur (elastisitas) dari pembuluh darah; 3) Penurunan fungsi ginjal yang alamiah. Jenis kelamin termasuk dalam faktor yang dapat mempengaruhi tekanan darah. Pada usia muda hipertensi lebih banyak diderita laki - laki dibanding wanita. Namun, setelah menapouse resiko hipertensi pada wanita meningkat. Hal tersebut diduga oleh perubahan hormon estrogen yang mempengaruhi distribusi lemak tubuh (Price \& Wilson, 2006).

Sebagian besar penderita hipertensi berpendidikan rendah. Pendidikan yang rendah dapat mempengaruhi perilaku pencegahan atau pengendalian tekanan darah. Hal ini menyebabkan tekanan darah penderita hipertensi tidak terkontrol hal ini dapat menyebabkan komplikasi penyakit jantung, ginjal dan stroke (Notoatmojo, 2002).

Tindakan light massage mempunyai sistem kerja yang sama sehingga mampu menurunkan tekanan darah pasien secara signifikan hal ini terlihat pada tabel 3. Light massage memberikan banyak manfaat, utamanya memperbaiki sirkulasi darah. Setiap sel 
dalam tubuh manusia membutuhkan suplai oksigen dan nutrien yang cukup untuk metabolisme yang didapat dari aliran darah. Aliran darah juga membawa produk sisa dan toksin dari sel, sehingga secara umum pijat meningkatkan kesehatan. Light massage memfasilitasi aliran energi positif dan komunikasi antar sistem organ seperti sistem kardiovaskular, pernafasan, pencernaan, urinari dan sebagainya untuk menjaga homeostasis. Light massage juga meningkatkan rasa nyaman dan relaksasi dengan menstimulasi sistem syaraf perifer (Moralez et al, 2008). Light massage dapat memicu pelepasan endorfin sehingga menghasilkan perasaan nyaman pada pasien, selain itu dapat terjadi reduksi hormon stres seperti adrenalin, kortisol, dan norephinefrin. Light massage akan memberi efek pada otot dan berefek pada alam bawah sadar di otak yang mengontrol nyeri dan emosi (Sagar, 2007), mengurangi tekanan pada otot sehingga meningkatkan relaksasi, memperbaiki sirkulasi darah, sehingga menurunkan tekanan darah sistolik dan diastolik (Wiyoto, 2011; Davis, 2005; Hernandez et al, 2000).

\section{KESIMPULAN DAN SARAN}

Penderita hipertensi meningkat setelah usia 50 tahun, proporsi perempuan lebih besar dibandingkan dengan laki laki dan sebagian besar penderita masih berpendidikan rendah. Light massage berpengaruh signifikan terhadap penurunan tekanan darah penderita hipertensi primer. Light massage dapat diterapkan sebagai terapi komplementer pada penderita hipertensi primer untuk pengendalian tekanan darah.

\section{DAFTAR RUJUKAN}

Aorella, M., Skoog, M., \& Carleson, J. (2005). Effects of Swedish massage onblood pressure.

Complementary Therapies in Clinical Practice, 11, 243-246.

Davis, Eshelman (2005). Panduan Relaksasi \& Reduksi Stres. Jakarta : EGC.

Gray. Huon H, Keith D. Dawkins, John M. Morgan, Iain A. Simpson. (2009) Lecture Notes : Kardiologi. Edisi ke empat. Jakarta: Erlangga

Hernandez, R., Field, T., Krasnegor, J., Theakston, H., Hossain, Z. \& Burman, I. (2000). High blood pressure and associated symptoms were reduced by massage therapy. Journal of Bodywork and Movement Therapies, 4(1), 31-38.

Junaidi, Iskandar. (2010) Hipertensi : Pengenalan, Pencegahan dan Pengobatan. Jakarta : PT Bhuana Ilmu Populer.

Morales, M. A., Olea, N., Martínez, M. M., Lozano, A. H., Rodriguez, C. R., and Rodriguez, L.D. (2008). Psychophysiological effects of massage-myofascial release after exercise: a randomized shamcontrol study.The journal of alternative and complementary medicine,4: 1223-1229.

Price,S.A.,Wilson,L.M. (2006). Patofisiologi. Volume 2. Edisi 6. Jakarta: EGC.

Riskesdas. (2013). Laporan Riset Kesehatan Dasar Tahun 2013. Jakarta : Badan Penelitian Dan Pengembangan Kesehatan Kementerian Kesehatan RI.

Shapo L, Pomerleau J, McKee M. (2003). Epidemiology of Hypertension and Associated Cardiovascular Risk 
Factors in Albania. Journal Epidemiology Community Health 5(7):734-739

Sigarlaki, Herke J.O. (2006) Karakteristik dan Faktor Berhubungan dengan Hipertensi di Desa Bocor, Kecamatan Bulus Pesantren, Kabupaten Kebumen, Jawa Tengah. Makara Kesehatan. (10): 76-88.

Simone, Giovani de., Richard B. Deveraux., Marcello Chimalli., Lyle G. Best., Elisa T. Lee., Thomas K. Welty. (2005) Association of Blood Pressure With Blood Viscosity in American Indians : The Strong Heart Study. Hypertension Journal of The American Heart Association. (45): 625-630.

Smeltzer, Suzanne C. (2008) Buku Ajar Medikal Bedah Brunner \& Suddarth/ editor, Suzanne C. Smeltzer, Brenda G. Bare ; alih bahasa, Agung

Upoyo,A.S., Mulyono, Hidayat, Anam,K. (2014). Tausiyah Untuk Pengendalian Tekanan Darah di Wilayah Kerja Puskesmas Purwokerto Timur, Laporan Penelitian, Unsoed, Purwokerto, belum dipublikasikan

Wiyoto, B. T. (2011). Remedial massage: Panduan pijat bagi fisioterapis, praktisi, dan instruktur. Yogyakarta: Nurha Medika 